\title{
TOWARDS SMART GOVERNMENT WITH A THEORETICAL STRATEGY MODEL
}

\author{
Meriem Bensaid and Salah Baina \\ ENSIAS, Mohammed V University in Rabat-Morocco
}

\begin{abstract}
The concept of smartness gains more and more significant importance in public sector transformation and the governments are beginning to take the paradigm of electronic government to a new stage to engage with citizens, co-develop policies, adopt creative thinking, enable a citizen-centric public service, and adopt innovation as a core value to raise the quality of life of citizens and enhance economic growth. In this respect, this paper performed a comprehensive literature review analysis to the identified smart government approaches. The Most important outcome is a Smart Government Strategy Meta Model which shows that Smart government is a whole effort which can be thought of in terms of three paradigms: 1.Smart participation approach 2.Competentness approach 2.Entrepreneurial approach. These three pillars rely on three enablers: Data, Smart capabilities and innovation.
\end{abstract}

\section{KEYWORDS}

Smart Government, Innovation, Digital Transformation, Smart Services, Smart Citizen

\section{INTRODUCTION}

The Digital Transformation of the public sector is a continuous process of transformational change of the way government work internally and externally in which the ICT role is changing over the time (Lips/2012, Millard et al. /2007, Huijboom et al. /2009b, Traunmuiller et al. /2003). In the literature, the ICT use in public administration is seen as a driver of efficiency and effectiveness by rationalizing existing process or as a tool to radically re-think the public sector and its external relationships re-engineer processes and organizations (Cordella et al./2012) and build new ways of interacting with citizens and businesses. Several concepts exist to assess the level of digital transformation development in the public sector. Indeed, as public administration grew in maturity in their use of ICT, they shift from Electronic Government where information and communication technologies (ICTs), and particularly the internet is seen as a tool to achieve better government $(\boldsymbol{O E C D / 2 0 1 4 )}$ to Digital Government where the use of digital technologies is an integrated part of governments' modernization strategies, to create public value.

However, on the one hand Public Administration faces the challenge of integrating emerging technologies more coherently and sustainably, on the other hand the technology and sup-ply-side focus of most benchmarks, indexes and rankings fail to explain the discrepancies between the availability and the use of online public services (Meyerhoff Nielsen/2014; Meyerhoff Nielsen and Igari/2012).

This fact also applies to the Moroccan Public Sector which is committed over the past two decades to embed ICT as a core function for public administrations to increase government effectiveness, efficiency, accountability and to establish better governance, responsive and open government (Digital Government Review of Morocco, OECD/2018). The COVID-19 pandemic has certainly confirmed the role of ICT as an important tool to improve the performance of the administration, while maintaining the physical distance with the citizen. But the challenge today for the Moroccan public sector is no longer to introduce emerging technologies into public sector but to align with advances in smart technologies, better informed and connected citizens, and global connected economies, this force Moroccan public administration to rethink their role and to take steps to become Smart (Smart government) and resilient; it's about a continuous effort and not a specific goal. 
Many approaches exists that present different perspectives to Smart Government according which, the concept of smartness in the public sector are the outcome of a set of the element : open data, Sharing, Service Integration, Innovation, citizen participation, information transparency, co-develop policies all supported by emerging technologies (e.g., big data, open government data, IOT ....etc.).

The aims of this research is to use the descriptive analysis for the identified academic literature, governmental and non-governmental report that relates to both smart government and Digital Transformation evolution and driving forces of the enterprise. The objectives is to extract the knowledge and expertise obtained in the private sector and to discuss how such efforts and their results can be applied to existing research perspectives to smart government in order to identify the majors paradigms of smartness in the Public Sector and map them into a Smart Government Strategy Meta Model model for smart citizen (DIY Citizenship", Ratto and Boler /2014).

To do so, firstly this paper provides related literature on the subject of Smart Government. The next section enlightens about features of Smart Government throught the theoretical strategy model proposed, and finally conclusion and future work.

\section{LITERATURE REVIEW}

\subsection{Understanding Smart Government}

In the narrower sense, the term SMART is used as a synonym of modern and intelligent and it is increasingly used in different contexts with different meanings (smart phones, smart home, smart industry, smart cities, smart governance, smart government ... etc). In Smart Government context, the concept of SMART refers to (Petrov/2014):

- Social : Personalized and citizen-friendly service delivery ;

- Mobile : Using the latest mobile technologies to deliver information and services, and get contributions from citizens, wherever and whenever they want ;

- Radical-openness : “open by design” transforms accountability and transparency, engages citizens in co-creation and enable businesses to use data to innovative new services ;

- Trust: Effective cybersecurity so that services are resilient, available and protection privacy.

The smart government term initially appeared in 2010 and various smart government meanings have been provided by scholars since then, however there is a common consensus according to which, Smart Government has been coined to describe the next generation of government transformation (Table 1).

Table 1. The paradigm shift for smart Government (Charalabidis/ 2015)

\begin{tabular}{|c|c|c|c|}
\hline & \multicolumn{1}{|c|}{-Government } & Open government & Smart Gov \\
\hline Concept & that work well & that opens to people & that think \\
\hline Goal & $\begin{array}{l}\text { how to do internal : Process } \\
\text { innovation }\end{array}$ & $\begin{array}{c}\text { how to do external : Governance } \\
\text { innovation } \\
\text { Key ICT area }\end{array}$ & $\begin{array}{c}\text { Infrastructures \& Organisation } \\
\text { innovation }\end{array}$ \\
\hline
\end{tabular}

Some of these approaches are given by anowski/2015, Cornadie and Choenni/2014, who relate the smartness of the public sector to the power (data-smart government). From a similar viewpoint, Harsh and Ichalkaranje/2015 consider that governments utilize the power of "data" in their attempt to improve public services; to enable an integrated, seamless service experience; to engage with citizens; to co-develop policies; and to implement solutions for well-being of the community. While Mellouli et al./2014, Cellary/2013 and Puron-Cid /2014 define it as the extensive use of technology by governments to perform governmental tasks. On the other hand, Gil Garcia et al./2014 conclude that smart government is a creative mix of emerging technologies and innovation in the public sector. Other corresponding definitions to smart government consider it as the next step for e-government, with the use of innovation (Savoldelli et al. /2014) or as the next step of 
open government with the engagement of citizens, accountability and interoperability (Veljković et al./2014, Jiménez et al/2014).Smart government is also defined by Kliksberg's/2000 as government that focuses on its strategic roles in society, with an institutional design and a development of managerial capacities that enable it to perform its roles in a highly effective; Moreover, Netten et al. /2016, Rubel/2014 approaches Smart government as: "Interoperability, The implementation of a set of business processes and underlying ICT capabilities that enable seamless information flow across government agencies and programs, to become intuitive in providing high quality citizen services across all government programs and activity domains". Finally, L.G.Anthopoulos/2017 define smart government as the evolution of both digital (e-government and open government and of smart city at a local level. The most important outcome of his study is "A unified smart government framework" that he compared with the Smart government conceptual framework given by Gil-Garcia et al. /2016.

\subsubsection{Smart Government Conceptual Framework (Gil-Garcia et al, 2016)}

The dimensions are: Openness as a synonym of transparency, information access, and accountability; Citizen Centricity by providing personalized information and service; Citizen Engagement as synonym of e-Participation as an enabler for a stronger and more intelligent collaboration between citizens and governments; Evidence-based decision making as intensive use of data to make better decision; Entrepreneurialism as an enabler of an attractive ecosystem for businesses and a better quality of life for individuals; Effectiveness and Efficiency as a benefit of e-government; Technology savviness as o tool to have an expert knowledge on the use of information technology tools; Creativity as the process through which new ideas are produced in both public service, internal process or public governance; Innovation as the process through which those ideas are implemented; Integration as an enabler for better communication, response, coordination; Sustainability which refers to the ecological implications of growth; Equality in order to reduce social exclusion by ensuring that citizens have equitable access to education, training, and services...etc; Resiliency as the ability to respond to their citizens in cases of emergency and disaster.

\subsubsection{Unified Smart Government Framework (Anthopoulos, 2017)}

It is a scientific Model according which building a Smart government is a whole effort which can be thought of in terms of three pillars: Digital Government, Open Government, and Smart City at a local level. The principal aims of Digital Government are to transform the relation-ship between government and citizens via smart services, key-enablers deployment and Interoperability and result in an increased government effectiveness and efficiency. On the other hand, open Government can modernize public service delivery via openness and promote more citizen engagement in politics, it has the potential to change the way that people view government as more accountable. Moreover, Smart cities are more likely to address smart city government, while smart solutions enhance local economic growth and evidence-based policy making. Finally, Data and emerging technologies accompanied by innovation in the public sector depicts the key components that drive the development of the second ring.

\subsubsection{Analysis - Literature Review}

- The smart government conceptual framework (Gil-Garcia et al. /2016), which is a multidimensional concept with very diverse components and elements, identifies and defines the goals (WHY) that a smart administration should achieve in the future without describing the means (HOW) to achieve them. In addition, those dimensions are related, some of them are the values attained from smart government; while most of them may be seen as a means to this values. In the following table (Table 2), we propose a classification of these dimensions : 
Table 2. Smart gov Outcomes/ Outputs/Means

\begin{tabular}{|c|c|c|}
\hline Outcome/ Why & Means / How & Description \\
\hline \multirow[t]{3}{*}{ Citizen engagement } & Openness & $\begin{array}{l}\text { Openness provides information for citizens } \\
\text { and lead to better communication which } \\
\text { actively engages citizens }\end{array}$ \\
\hline & Innovation & in terms of Policy innovation \\
\hline & Technology savviness & $\begin{array}{l}\text { Networked technologies also provide new } \\
\text { opportunities for citizens to participate in } \\
\text { and influence, develop, and test smart city } \\
\text { policies (Pereira, Cunha, Lampoltshammer, } \\
\text { Parycek \& Testa/2017) }\end{array}$ \\
\hline \multirow[t]{5}{*}{$\begin{array}{l}\text { Efficiency \& } \\
\text { Effectiveness }\end{array}$} & $\begin{array}{l}\text { Evidence-based decision } \\
\text { making }\end{array}$ & $\begin{array}{l}\text { Exploiting data in a more systematic rather } \\
\text { than ad-hoc way to. }\end{array}$ \\
\hline & Creativity & $\begin{array}{l}\text { creative thinking as a way of removing rigid } \\
\text { preconceptions and of opening ourselves to } \\
\text { complex phenomena which cannot always } \\
\text { be dealt with in a strictly logical manner } \\
\text { (Landry /2012) }\end{array}$ \\
\hline & Integration & $\begin{array}{l}\text { Information integration in government can } \\
\text { reduce duplication of data collection, } \\
\text { coordinate efforts, and help local, state, and } \\
\text { national level administrations become more } \\
\text { efficient, transparent, and deliver better } \\
\text { quality services (Gil-Garcia/2012a, 2012b). }\end{array}$ \\
\hline & Technology savviness & $\begin{array}{l}\text { ICT in government can reach goals beyond } \\
\text { costs reduction and service quality } \\
\text { improvement }\end{array}$ \\
\hline & Innovation & $\begin{array}{l}\text { innovation and intelligence for local or } \\
\text { governments as the means to increase their } \\
\text { efficiency and effectiveness (Taylor } / 2015 \\
\text { and Gil-Garcia et al./2013, 2015a) }\end{array}$ \\
\hline \multirow[t]{6}{*}{ Entrepreneurialism } & Citizen Centricity & Meeting the Needs of the Customer \\
\hline & Equality & equal accessibility to public services \\
\hline & Resiliency & $\begin{array}{l}\text { Proactiveness as a key dimension of (Covin } \\
\text { \& Slevin/1989; Miller/1983; Morris \& } \\
\text { Sexton/1996) Anticipatory Government: } \\
\text { Prevention Rather than Cure }\end{array}$ \\
\hline & Sustainability & $\begin{array}{l}\text { By promoting the concept of } \\
\text { entrepreneurship, Smart government } \\
\text { initiatives can contribute in many ways to } \\
\text { the achievement of the sustainable } \\
\text { development goals }\end{array}$ \\
\hline & Technology savviness & $\begin{array}{l}\text { Creating public value through smart } \\
\text { technologies }\end{array}$ \\
\hline & Innovation & Innovative Public Services \\
\hline
\end{tabular}

Thus, it can be concluded that implementation of strategic approaches to transition towards smart government can focus on three core values supported by Technology, Innovation and Data: 1. Citizen Engagement, 2. Efficiency \& Effectiveness as a result of creativity which is related to human capital, horizontal and vertical integration and Evidence-based decision making...etc., 3. Entrepreneurialism whish which is essentially based on smart services. 
- Unified smart government framework (L.G. Anthopoulos/2017): by analyzing the three pillars on which this model is based, we can consider Digital Government, Open Government, and Smart City at a local level as complementary and interrelated concepts. Indeed, the potential of digital facilitate instant interaction with citizens and promote accountability. In addition Open government data and information based on technological trends foster innovation in the public and the private sector and promote social and economic development of a society as a whole (economic growth); these same trends are transforming citizens into coproducers of information (citizens engagement). In fact, the Unified smart government framework consider that the Smart Government is a multidimensional approach which encompasses both Digital/Open Government initiatives and Smart City at a local level ., but it doesn't propose a clear process to enable better decisions about the development of smart government strategies and projects (When does a smart government transformation start? And, where to begin?).

To conclude, Figure 1 synthesize all the smart government approaches given by the literatures above.

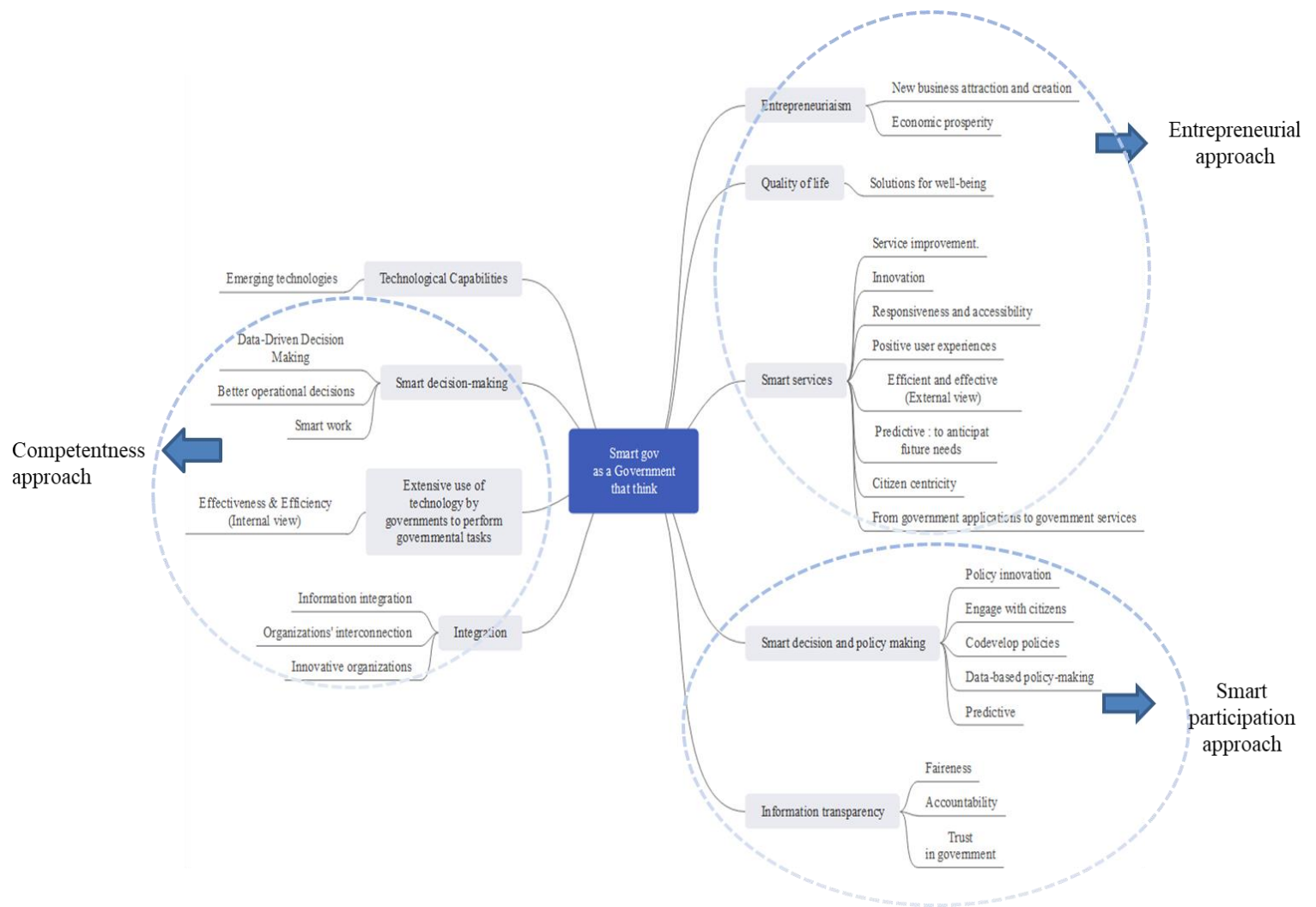

Figure 1. Smart government approaches synthesis

\section{SMART GOVERNMENT STRATEGY META MODEL}

Based on all those definitions to smart government (Figure 1), we can conclude that creating a Smart Government ecosystem does not only require just the appropriate digital tools but also well-functioning teams able to implement these smart technologies, along with necessary policies through co creation with citizens and policy innovation ( smart engagement).

Thus, government transformation towards smart government may be seen as relies on three major paradigms (Figure 2): 


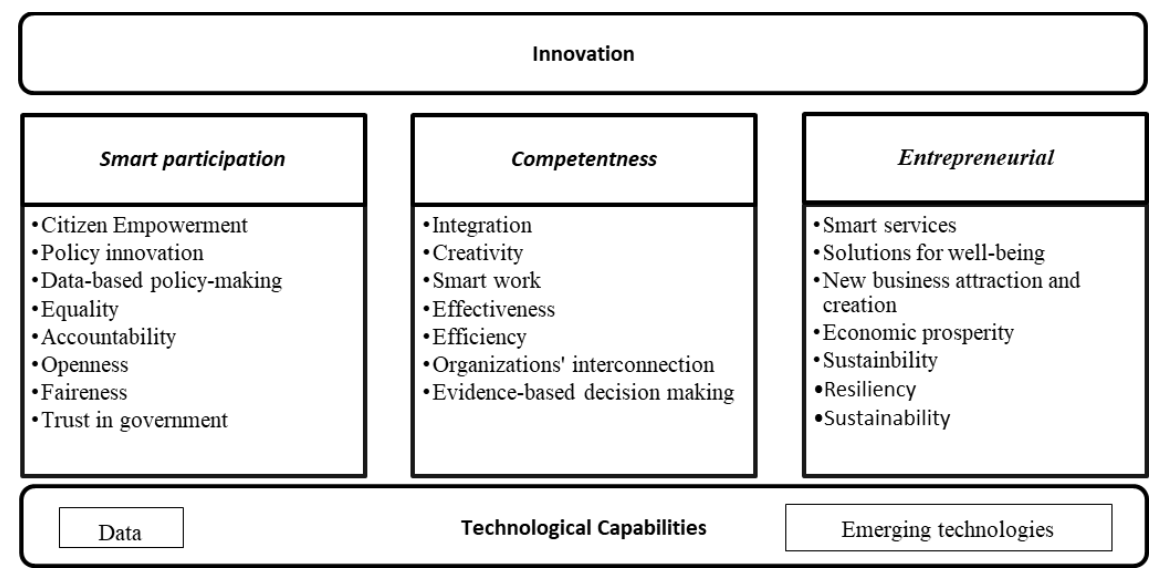

Figure 2. Smat govenrment Strategy Meta Model

- Smart participation approach: in term of policy making, this paradigm focuses on policy making processes to increase the society's trust and confidence in government and to promote e-democracy through more participatory and more responsibility; This approach represents the shift from open participation (reactive, responsive disclosure of public information) to smart participation which really gives power to citizens and aims to strength Citizen Empowerment. According to the categorization given by the OECD/2001 to the interaction between citizens and government, this smart participation covers the following three stages:

- Smart Enabling : government produces and delivers information for use by citizens (information transparency, Open Any Data);

○ Smart Engagement : governments ask for and receive citizens' feedback on a policy issue (evidence-based policy making);

- Smart Empowerment : in which citizens actively engage in the policy-making process (Codevelop policies and Policy innovation);

- Competentness approach: aims to enhance internal efficiency and effectiveness through a set of concepts: creativity, smart work, Data-Driven Decision Making cross-organizational information as well as knowledge integration. In addition while the need for interdisciplinary teams is important to any Electronic Government initiatives, it is particularly crucial for implementing Smart Government concept.

- Entrepreneurial approach: mainly aims at increasing the accessibility, responsiveness, smartness of public services and economic growth as well as citizens' well-being. This approach refers to the ability of governments to anticipate a need and to respond effectively in the face of external change.

This Smart government Strategy Meta Model aims to describe a standard in order to help governments developing and implementing their Smart government Strategy.

\section{CONCLUSION}

Governmental transformation to become smart is about a continuous effort and not a specific goal, this new phenomenon disrupt on the one hand the process of public policy making through data-based decisions and citizen engagement, on the other hand it provide predictive, adaptable, innovative, sustainable, effective and efficient public services which are accessible anytime, anywhere and from any device. Thus, Smart government that relies on smart technologies (IOT, Big Data, and IA...etc) complement both the e-government and open government concepts and introduce new ones such as innovation, creativity, entrepreneurialism, resilience and sustainability (Gil-Garcia and al. /2016). For future work, on the one hand, we will continue to develop the 
model shown in figure 4 by trying to cover the maximum amount of literature concerning smart gov. On the other hand, we will enhance this model with inter-national smart government and digitalization strategies well as the advances in the private sector in terms of digital transformation; the principal objective is to identify the underlying factors that control those elements and to examine the interrelationship between these components.

\section{REFERENCES}

Anthopoulos, L., 2017. Smart Government: A New Adjective to Government Transformation or a Trick? Public Administration and Information Technology, pp. 263-293.

Charalabidis, Y., Loukis, E., Alexopoulos, C. and Lachana, Z., 2019. The Three Generations of Electronic Government: From Service Provision to Open Data and to Policy Analytics. Lecture Notes in Computer Science, pp. 3-17.

Cordella, A. and Bonina, C., 2012. A public value perspective for ICT enabled public sector reforms: A theoretical reflection. Government Information Quarterly, 29(4), pp. 512-520.

Featherman, C., 2016. DIY citizenship: Critical making and social media. New Media \& Society, 18(4), pp. 672-674.

Gil-Garcia, J., Helbig, N. and Ojo, A., 2014. Being smart: Emerging technologies and innovation in the public sector. Government Information Quarterly, 31, pp. I1-I8.

Gil-Garcia, J., Zhang, J. and Puron-Cid, G., 2016. Conceptualizing smartness in government: An integrative and multi-dimensional view. Government Information Quarterly, 33(3), pp. 524-534.

Kliksberg, B., 2000. Rebuilding the State for Social Development: Towards 'Smart Government'. International Review of Administrative Sciences, 66(2), pp. 241-257.

Lips, M., 2012. E-Government is dead: Long live Public Administration 2.0. Information Polity, 17(3, 4), pp. 239-250.

Mellouli, S., Luna-Reyes, L. and Zhang, J., 2014. Smart government, citizen participation and open data. Information Polity, 19(1,2), pp. 1-4.

Nam, T., 2013. Government 3.0 in Korea. Proceedings of the 7th International Conference on Theory and Practice of Electronic Governance.

Nceg.gov.in. 2021. [online] Available at: <https://www.nceg.gov.in/sites/default/files/nceg2014/presentation/day1_session3_World_Bank_Oleg_Petrov.pdf> [Accessed 20 February 2021].

Oecd.org. 2021. [online] Available at: <http://www.oecd.org/gov/digital-government/recommendation-digitalgovernment-strategies.pdf> [Accessed 20 February 2021].

Public Administration and Information Technology, 2017. Government 3.0 - Next Generation Government Technology Infrastructure and Services.

Sun, P., Ku, C. and Shih, D., 2015. An implementation framework for E-Government 2.0. Telematics and Informatics, 32(3), pp. 504-520.

Viale Pereira, G., Cunha, M., Lampoltshammer, T., Parycek, P. and Testa, M., 2017. Increasing collaboration and participation in smart city governance: a cross-case analysis of smart city initiatives. Information Technology for Development, 23(3), pp. 526-553.

Winstanley, P., 2017. Public Administration for the Next Generation. Public Administration and Information Technology, pp. 27-36. 